\title{
THE THERMAL AND STRUCTURAL ANALYSIS OF NEW BICOMPONENT BINDERS FOR MOULDING SANDS CONSISTING OF FURFURYL RESIN AND POLYCAPROLACTONE (PCL)
}

\begin{abstract}
The aim of the article is thermal and structural analysis of new two-component binders for foundry moulding sands. The previous research showed the possibility of using biodegradable materials as binders or parts of binders' compositions for foundry moulding and core sands. This paper is concentrated on estimating the influence of PCL on phenol-furfuryl resin thermal destruction (measured by derivatographic research) and its structure (measured by FTiR technology). The research proved that addition of new biodegradable additive PCL in the amount of 5-15\% to the phenol-furfuryl resin doesn't change the resin thermal destruction course but it results in appearance of a new band in two-component binder structure. What's more there has been noticed a growth of intensity for band at wavenumber $1730 \mathrm{~cm}^{-1}(\mathrm{C}=\mathrm{O})$ with the increasing addition of PCL.

Keywords: innovative foundry technologies and materials, moulding sands, furfuryl resin, polycaprolactone (PCL), spectroscopic studies (FTiR)
\end{abstract}

\section{Introduction}

According to the tendencies observed in recent years, moulding processes must meet high requirements connected to environmental protection.

One of scientific research directions is a gradual replacement of binding materials produced from petrochemical origin, with biopolymers coming from renewable resources. It is consistent with the conception of sustainable development, which is one of the priorities of the European Community policy. In the 90's the General Motors Co. elaborated a new binding system based on protein composition GMBOND [1]. The materials in the protein binder come from natural renewable resources and consist of polypeptide chains, which are non-toxic (safe) for the environment. K. Rusin's scientific group [2] tested possibilities of using biogenic binders based on proteins obtained from by-products of pharmacy industry production. The group tested water soluble not toxic polymers, including different polypeptide molecules with long amino acids chains. B. Grabowska [3-4] proposed use of aqueous biodegradable polymeric compositions consisting of acrylic derivatives and modified natural polymers as foundry moulding sands' binders (BioCo binders). Moulding sands with BioCo binders can be used in iron castings production [4]

The use of additives to the binders to improve moulding sands properties is the newest trend of global corporations in the production of foundry materials [5].

Literature data [6-8] shows that there is a possibility of using biodegradable materials as additives for petrochemical materials to increase their biodegradability. For example poly $(\varepsilon-$ caprolactone) (PCL) has a unique characteristic - compatibility with various other polymers. PCL is semi-compatible or mechanically compatible with some polymers such as PVAc (polyvinyl acetate), PS (polystyrene), polycarbonate, etc. Moreover, PCL is compatible with other polymers such as PVC (polyvinyl chloride), SAN (styrene acrylonitrile copolymer), poly(hydroxy ether), etc. This characteristic of PCL enables the formation of various biodisintegrable blends using it as a biodegradable component [6]. Primary studies of biodisintegrable polymer blends using PCL as a biodegradable component started with $\mathrm{PCL} /$ polyolefin blend systems based on polyolefins such as LDPE (low density polyethylene) and PP (polypropylene). More detailed studies on the biodegradability of PCL/polyolefin blend including the relationship between the biodegradability and the phase structure were performed by Iwamoto and Tokiwa [7]. Further advantages of using biodegradable polymers, such as PCL, as additives might include increase in flexibility of moulding sands with new two-component resins. The use of PCL as a plasticizer for plastics is not a new matter. From a technological point of view, the use of plasticizers for polymers is very important and widely used in various industries. In 1966 the use of PCL as a plasticizer for polyvinyl chloride (PVC) was patented. Polycaprolactone was used as a plasticizer in blends of: aliphatic polyesters, cellulose esters, aromatic polyesters, polycarbonates, polymers containing styrene (eg. Polystyrene), polyolefins, block copolymers, and in foundry resin type NOVOLAK [8-9]. 


\section{Own research}

A broad analysis of literature data and own research led the authors to a new perspective on the production of moulding and core sands. The idea is based on partial replacement of synthetic foundry resins with biodegradable materials, to improve their properties [9]. This approach will reduce the technological costs in relation to approach which used only biodegradable material as moulding sand's binder. At the same time it will allow the modernization of well-known and widely used mould and core preparation technologies.

Preliminary research [10] has shown that the moulding sands with biodegradable materials as binders are not only lower in toxicity but they have a greater capacity to regenerate mechanically than traditional synthetic resin moulding sands. It can be concluded that the partial replacement of the petrochemical origin binder with biodegradable material will improve the quality of tested moulding sands [9-11]. In addition, the use of polycaprolactone as a component of the new binder can improve the resistance to deformation of the moulding sand at ambient temperature, known in the literature as flexibility/elasticity [12-13].

\subsection{The materials investigated as components of a new two-component binder}

The following materials were selected as components for the new binders:

- Phenol-furfuryl resin from Hüttenes-Albertus Company under the name of Kaltharz XA20. The study used furan resin that did not contain nitrogen, and the free formaldehyde content was in the range of $0.05-0.15 \%$. The amount of furfuryl alcohol was $78 \%$.

- Hardener from Hüttenes-Albertus Company under the name of Aktivator 100T3. An aqueous solution of paratoluenesulfonic acid.

- $\quad$ Polycaprolactone (PCL) from Polysciences, Inc. was used as a biodegradable additive and plasticizer in powdered form. It is a biodegradable polymer having an end hydroxyl group.

Selection of these materials is primarily based on the fact that PCL can be dissolved in the Kaltharz XA20 resin. There is therefore no need for an additional solvent to dissolve the biodegradable polymer.

\subsection{Measurements and discussion}

The influence of PCL on thermal degradation of phenolfurfuryl resin was tested by derivatographic research. The tests were carried out on the Iota derivatograph in the following measurement conditions: heating temperature range $20-1000^{\circ} \mathrm{C}$, heating rate $10^{\circ} \mathrm{C} / \mathrm{min}$. The measurement was conducted in oxygen atmosphere. Figures 1-2 show the derivatographic measurement results

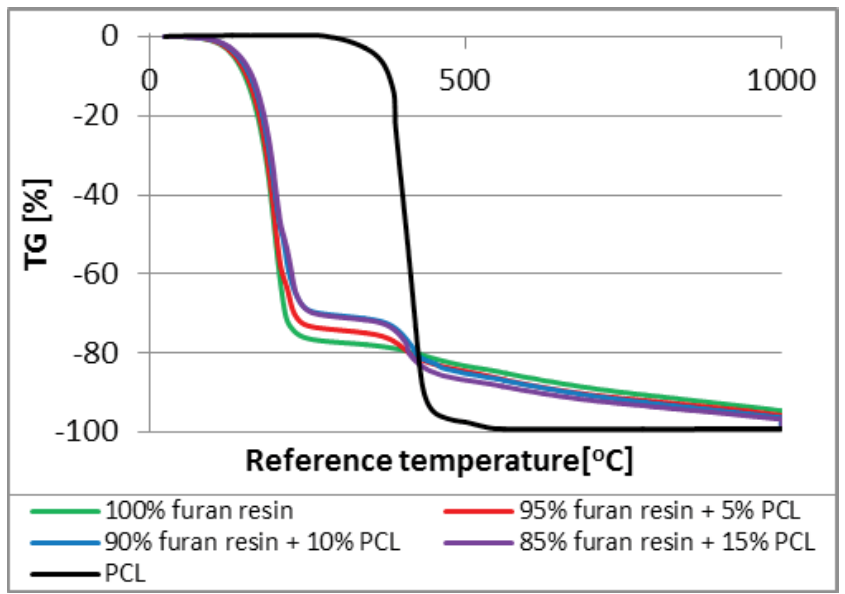

Fig. 1. TG curves of applied resins [9]

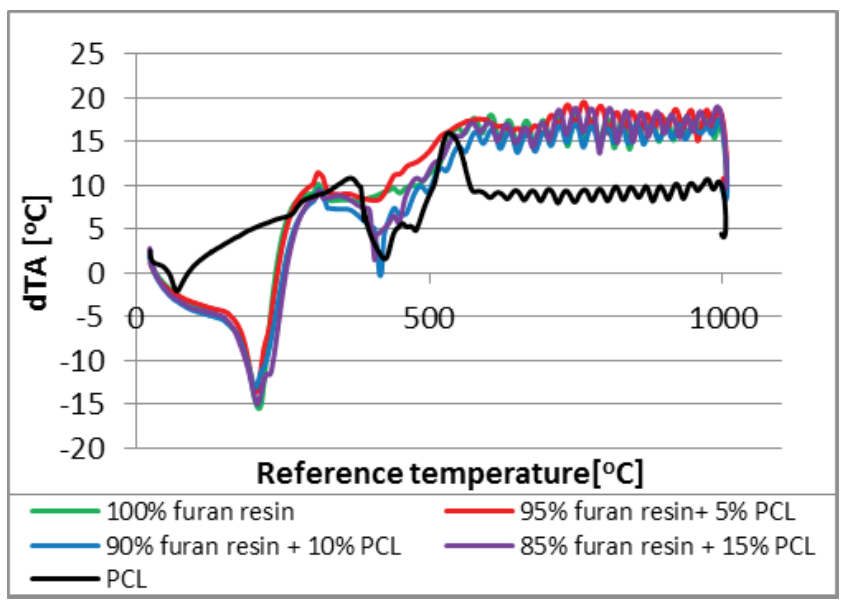

Fig. 2. DTA curves of applied resins [9]

The study showed that the phenol-furfuryl resin has a lower temperature of the beginning of thermal destruction (temperature approx. $120^{\circ} \mathrm{C}$ ). The violent process ends at a temperature of approx. $230^{\circ} \mathrm{C}$ and transitions into slow decay to approx. $820^{\circ} \mathrm{C}$. Thermal destruction of the biodegradable material (PCL) is very intense - starting at a temperature of approx. $370^{\circ} \mathrm{C}$ and ending at a temperature of approx. $450^{\circ} \mathrm{C}$. This means that the loss of PCL specimen weight begins much later than in commonly used moulding sand foundry resins and is more violent [9]. The thermal destruction of two-component adhesives process is similar to the TG curve of pure furfuryl resin (Fig. 1). It can be noted, however, that the destruction changes its course towards somewhat higher temperatures (Fig. 2). The changes are adequate to the percentage of the PCL material in the binder [9].

The next stage was spectroscopic studies (FTIR) of new binders. The aim of these studies was to determine the effect of used biodegradable material on the structure of the new twocomponent binder. Structural analyses were carried out using an Excalibur FTIR spectrometer with a standard DTGS detector and the resolving power of $4 \mathrm{~cm}^{-1}$. The spectra of samples were obtained at room temperature using the transmission technique (KBr pellet). A small amount of liquid binder was smeared onto a $\mathrm{KBr}$ pellet (prepared by pressing $\mathrm{KBr}$ powder under force of 
$8 \cdot 10^{3} \mathrm{~kg}$ ). The number of scans was constant for all samples. The results were registered for wave numbers from 4000 to 400 $\mathrm{cm}^{-1}$ with resolution $4 \mathrm{~cm}^{-1}$ as shown in Figs. 3-4 and Tables 1-2.

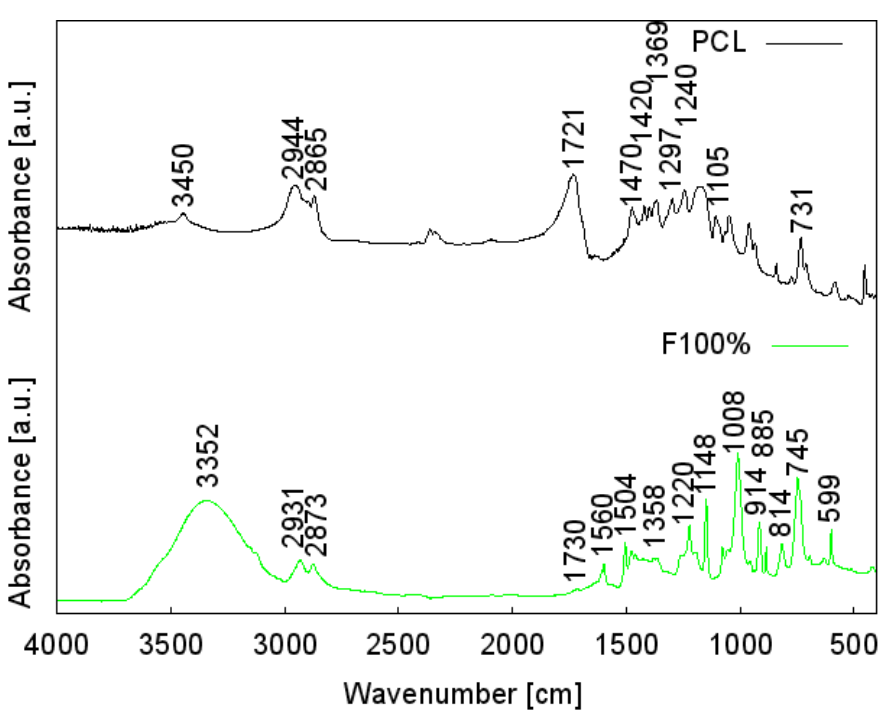

Fig. 3. FTIR spectrum of PCL and $100 \%$ furfuryl resin

Characteristic vibrations of the $\mathrm{O}-\mathrm{H}$ stretching bonds at wavenumber $3450 \mathrm{~cm}^{-1}$ can be identified in the PCL spectrum (Fig. 3, Table 1) [14]. Asymmetrical vibration of $\mathrm{CH}_{2}-\mathrm{O}$ were registered at $2944 \mathrm{~cm}^{-1}$ and balanced vibration of methylene groups $\mathrm{CH}_{2}$ at $2865 \mathrm{~cm}^{-1}$ [15-16]. The intense band characteristic of the carbonyl group is observed at a wavenumber $1721 \mathrm{~cm}^{-1}$ and is associated with the vibration of the $\mathrm{C}=\mathrm{O}$ aliphatic ester in PCL [15-16]. Band at $1470 \mathrm{~cm}^{-1}$ refers to the asymmetrical vibration of C-H of a methylene group [15]. The remaining bands in the $1470-1369 \mathrm{~cm}^{-1}$ and $1105-730 \mathrm{~cm}^{-1}$ are also in the vibration characteristic of $\mathrm{C}-\mathrm{H}$ bond [15,17-19]. In the wave number range 1297-1160 oscillation of C-O bonds occurs [15-18].

TABLE 1

Chosen wavenumbers with vibration descriptions for PCL

\begin{tabular}{|c|l|c|}
\hline \hline \multicolumn{2}{|c|}{ PCL } & Source \\
\hline $\begin{array}{c}\text { Wave- } \\
\text { number } \\
{\left[\mathbf{c m}^{-1}\right]}\end{array}$ & \multicolumn{1}{|c|}{ Description of vibrations } & {$[14]$} \\
\hline 3450 & $(-\mathrm{OH})$ peak & {$[15,16]$} \\
\hline 2944 & $(\mathrm{CH} 2-\mathrm{O})$ asymmetric elongation/stretching & {$[15,16]$} \\
\hline 2865 & $\left(\mathrm{CH}_{2}-\right)$ symmetric elongation/stretching & {$[15,16]$} \\
\hline 1721 & $\begin{array}{l}\left(\mathrm{CO}_{2}-\right) \text { stretching of carbonyl belonging to an } \\
\text { aliphatic ester }\end{array}$ & {$[15]$} \\
\hline 1470 & $(\mathrm{C}-\mathrm{H})$ asymmetric elongation in methylene & {$[17]$} \\
\hline 1420 & $\delta\left(\mathrm{CH}_{2}-\mathrm{CH}_{3}\right)$ & {$[18-19]$} \\
\hline 1369 & $\delta\left(\mathrm{CH}_{2}\right)$ & {$[16-18]$} \\
\hline 1297 & $\begin{array}{l}v_{\text {cr }}(\mathrm{C}-\mathrm{O}) \text { and } v_{\text {cr }}(\mathrm{C}-\mathrm{C}) \text { stretching in the crystalline } \\
\text { phase }\end{array}$ & {$[15-17]$} \\
\hline 1240 & $v_{\text {as }}(\mathrm{C}-\mathrm{O}-\mathrm{C})$ asymetric stretching & {$[20]$} \\
\hline 1160 & $\mathrm{C}-\mathrm{O}$ & {$[18-19]$} \\
\hline 1105 & $\mathrm{CH}_{2}$ & {$[15]$} \\
\hline 730 & $\begin{array}{l}\text { p }\left(\mathrm{CH}_{2}-\right) \text { asymmetric elongation of long } \mathrm{CH}_{2} \text { - chains } \\
\text { corresponding with the 1470 methylene group }\end{array}$ & \\
\hline
\end{tabular}

TABLE 2

Chosen wavenumbers with vibration descriptions for furfuryl resin

\begin{tabular}{|c|c|c|}
\hline \multicolumn{3}{|c|}{$100 \%$ Furfuryl resin } \\
\hline $\begin{array}{c}\text { Wave- } \\
\text { number } \\
{\left[\mathrm{cm}^{-1}\right]}\end{array}$ & Description of vibrations & Source \\
\hline 3352 & $(\mathrm{O}-\mathrm{H})$ & {$[21,22-23]$} \\
\hline 2931 & $(\mathrm{C}-\mathrm{H})$ & {$[22-25]$} \\
\hline 2873 & $(\mathrm{C}-\mathrm{H})$ & {$[22-25]$} \\
\hline 1730 & $(\mathrm{C}=\mathrm{O})$ & {$[26]$} \\
\hline 1560 & $(\mathrm{C}=\mathrm{C})$ & [27] \\
\hline 1358 & $\begin{array}{l}(\mathrm{OH}) \text { vibrations of the furan ring or of the } \\
\mathrm{OH} \text { phenolic deforming the bond along the } \\
\text { plane }\end{array}$ & {$[22-23]$} \\
\hline $\begin{array}{l}1220,1148, \\
1008\end{array}$ & Band recognized in cured resin & {$[22]$} \\
\hline $\begin{array}{l}914,885 \\
814\end{array}$ & $(\mathrm{C}-\mathrm{H})$ deforming vibrations of the furan ring & {$[21]$} \\
\hline 745 & $\begin{array}{l}\text { skeleton vibrations coming from bonds } \\
\text { found in furfuryl alcohol }\end{array}$ & {$[21]$} \\
\hline 599 & vibrations of the entire furan ring & [21] \\
\hline
\end{tabular}

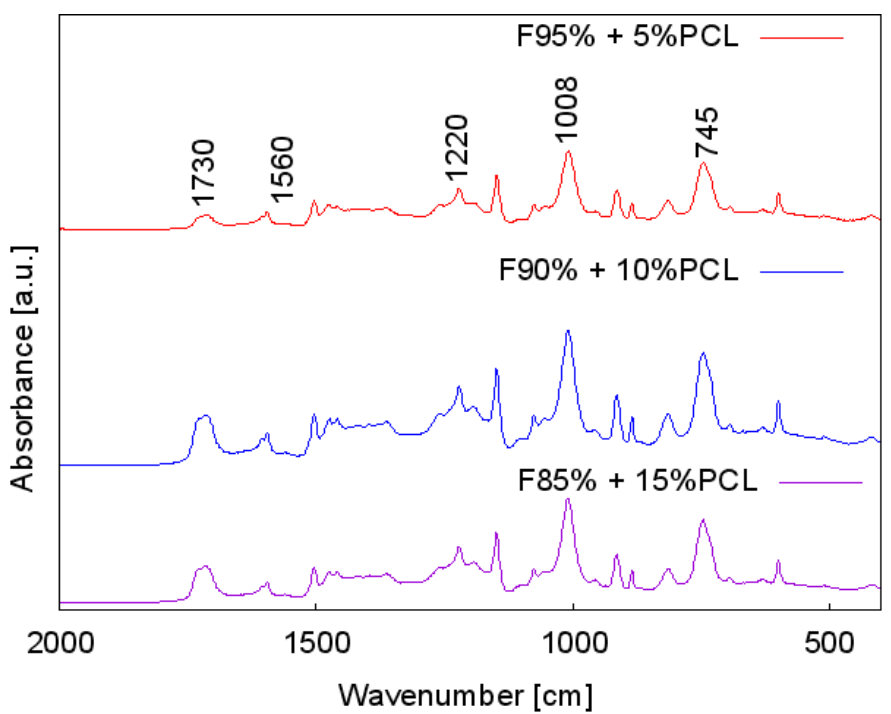

Fig. 4. FTIR spectrum of two-component binders

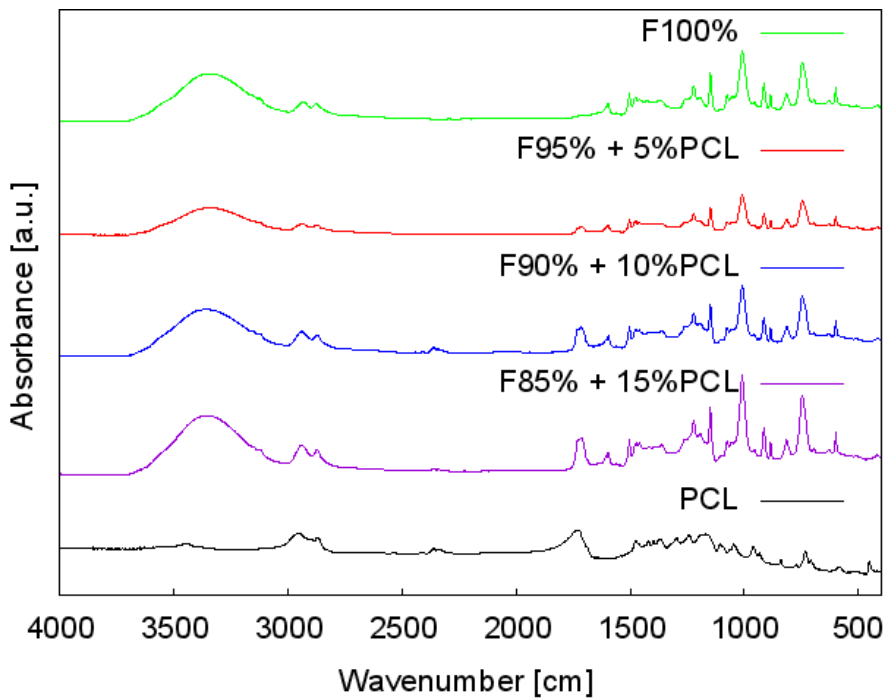

Fig. 5. FTIR curves for chosen resins and PCL 
PCL addition in the amount of $5-15 \%$ to the furan resin (Figs. 4-5) results in the appearance of a band at a wavenumber of $1105 \mathrm{~cm}^{-1}$ derived from the vibration of $\mathrm{CH}_{2}$ in PCL (Tables 1-2) [18-19]. There has also been a growth of intensity for band at wavenumber $1730 \mathrm{~cm}^{-1}$ caused by vibration of extending carbonyl bond $\mathrm{C}=\mathrm{O}$ with the increasing addition of PCL [26]. Other bands in the spectrum of the resin do not change with the increasing addition of PCL (Fig. 4-5).

\section{Conclusions}

Analysis of literature data and the author's own research yield the following conclusions:

- The biodegradable additive PCL in the amount of 5-15\% to the phenol-furan resin does not significantly affect the thermal degradation of phenol-furfuryl resin (TG, dTA curves). However this impact of PCL increases with its quantity.

- $\quad$ PCL addition in the amount of $5-15 \%$ to the phenol-furan resin results in the appearance of a new band at a wavenumber of $1105 \mathrm{~cm}^{-1}$ and a growth of intensity for band at wavenumber $1730 \mathrm{~cm}^{-1}$ in two-component binders. It is possible that PCL came into the phenol-furfuryl resin structure but such a claim must be proved by different type of research.

\section{Acknowledgments}

Scientific research financed from AGH Research Project No 11.11.170. 318-3

\section{REFERENCES}

[1] J. Eastman, Modern Casting, 32- 34 (2000).

[2] D. Kramářová, J. Brandštetr, K. Rusín, P. Henzlová, Slévárenství, 60, 2-3, 71-73 (2003).

[3] B. Grabowska, M. Holtzer, R. Dańko, M. Górny, A. Bobrowski, E. Olejnik, Metalurgija 52, 1, 47-50 (2013).

[4] B. Grabowska, M. Szucki, J.Sz. Suchy, S. Eichholz, K. Hodor, Polimery 58, 1, 39-44 (2013).

[5] C. Fourberg, in: $5^{\text {th }}$ Conference 'Materiały formierskie i rdzeniarskie - teoria i praktyka', Lublin, Poland, 5-8.10.2016.
[6] E.-J. Choi, J.-K. Park, Polymer Degradat. Stabil. 52, 321-326 (1996).

[7] A. Iwamoto, Y. Tokiwa, Polymer Degradat. Stabil. 45, 2, 205-213 (1994).

[8] G.C. Eastmond, Advances in Polymer Science 149, 59-222 (2000).

[9] K. Major-Gabryś, A. Grabarczyk, St.M. Dobosz, J. Jakubski, Metalurgija 55, 2, 385-387 (2016).

[10] K. Major-Gabryś, Odlewnicze masy formierskie i rdzeniowe przyjazne dla środowiska. 2016, Archives of Foundry Engineering, Gliwice.

[11] K. Major-Gabryś, China Foundry 12, 5, 375-381 (2015).

[12] P. Gröning, S. Schreckenberg, K. Jenrich, Giesserei 102, 01, 42-47 (2015).

[13] A. Grabarczyk, St.M. Dobosz, K. Major-Gabryś, J. Jakubski, J. Morek, Archives of Foundry Engineering 15, 4, 39-42 (2015).

[14] K. Bassi, J.E. Gough, M. Zakikhani, S. Downes, Journal of Tissue Engineering, 1-9 (2011).

[15] R. Hernández, O.C. Contreras, J.C. Acevedo, L.G.N. Moreno, American Journal of Polymer Science 3, 4, 70-75 (2013).

[16] T. Elzein, M. Nasser-Eddine, Ch. Delaite, S. Bistac, P. Dumas, Journal of Colloid and Interference Science 273, 381-387 (2003).

[17] J. Krzaczkowska, Z. Fojud, M. Kozak, S. Jurga, Acta Physica Polonica 108, 187-197 (2005).

[18] M. Bora, J.N. Ganguli, D.K. Dutta, Termochimica Acta 2, 346-415 (2000).

[19] M.S. Salil, J.P. Shrivastava, S.K. Pattanayak, Chemical Geology 136, 1-2, 25-32 (1997).

[20] S. Rejendran, T. Uma, Journal of Power Sources 88, 2, 282-285 (2000).

[21] H. Rehne, G. Homgmei, T. Yaoji, L. Quingyun, Research \& Development 5, 161-165 (2011).

[22] A. Bobrowski, B. Grabowska, Metallurgy of Foundry Engineering 38, 1, 73-80 (2012).

[23] C. L. Burket, R. Rajagopalan,A. P. Marencic, K. Dronvajjala, H. C. Foley, Carbon 44, 2957-2963 (2006).

[24] D. Rosu, L. Rosu, M. Brebu, Journal of Analytical and Applied Pyrolisys 92, 10-18 (2011).

[25] C.P. Reghunadhan Nair, R.L. Bindu, K.N. Ninan, Polymer Degradation and Stability 73, 251-257 (2002).

[26] Y. Liu, J. Gao, R. Zhang, Polymer Degradation and Stability 77, 495-501 (2002).

[27] R. González, J.M. Figueroa, H. González, European Polymer Journal 38, 287-297 (2002). 